\title{
Environment and Women Entrepreneurs in Albania
}

\author{
Azra Zmijanej \\ University of Shkodra "Luigj Gurakuqi", Albania \\ zmijaniazra@yahoo.com
}

Abstract

\begin{abstract}
Albania has become a much attractive environment for the development of women's entrepreneurship. If women are provided with the necessary resources, skills and opportunities to create strong businesses, and if they are willing to pursue the growth potential of these companies due to a more favorable environment, will benefit from economic growth. Promoting women entrepreneurs will create employment, empowerment and gender equality. But in fact the woman in the enterprise faces many challenges caused by various factors. In this study sought to analyze women entrepreneurs and their work environment in Albania and the challenges they face. It will identify policies for the development of enterprises managed by women in Albania. The data for this study were provided by various sources of literature. Secondary data are the result of the review of a wide and contemporary literature about women entrepreneurs, the environment and challenges. Primary data collection were carried out a series of in-depth personal interviews with some powerful women entrepreneurs in Albania. The results of this study show that woman has won respect in society and plays an important role in governance, political and private sector. It is clearly evidenced that women are becoming increasingly involved in social and economic life of the country and that an enabling environment for women's entrepreneurship, consolidates and supports their role.
\end{abstract}

Keywords: enterprising woman, empowering, environment, economic growth.

\section{Introduction}

When it comes to gender equality in Albania, mainly it is meant to advance the position of women in society. Looking at the situation of women's performance in the labor market, indicators are quite worrisome. Women are subject to a higher rate and longer term unemployment and reduced participation in the labor market (60\% of women) (LFS, 2011), whilst their involvement in private self-employment activities is lower (Miluka, 2011) as compared to men in Albania. Another feature is women concentration in sectors with low productivity and a high rate of informality, such as agriculture and manufacturing. Seemingly, they are less involved in industry and service sectors as compared to men (ISB, 2013). Such concentration is partly a result of the educational system and of women's overwhelming responsibility to tend to domestic chores. As a result of occupational segregation and higher discontinuity of experience in the labor market (due to weak child care provisions) there are evident wage differentials for women as compared to men (MSWY, 2014). Women's time allocation to unpaid work and domestic care services and duties is much higher than men. Thus, according to Albania Time Use Survey 20102011 , women carry out $86 \%$ of unpaid work and $96 \%$ of domestic chores, which is found to be an opportunity cost for paid work. This allocation is more time consuming for rural women and women with small children (INSTAT, 2012). LSMS (2008) indicates that a lower percentage of women are involved in full-time work and entitled to social security, whilst a larger number of women are situated at the bottom part of the wage pyramid in Albania. Same data indicate that access to education, work experience, availability of social support, and male labor complementarities in various activities where women are involved do positively influence labor force participation (ISB, 2013).

On the Education and Training front major concerns remain with respect to young girls and women education, especially in rural areas. The transfer rate from compulsory education to secondary education is lower for females compared to males (MES, 2013). High school girls from remote areas of Albania experience higher drop-out rates compared to the boys of the same age (ISB, 2013). There exists an under-presence of women in professional education (approximately $1 / 3$ of the total enrolments) mainly due to schools distance and locations (MES, 2012). Moreover the VET system is claimed to be prone to gender segregation where girls are mainly enrolled in agro-business, tourism, administration, hair-dressing and tailoring courses. Participation to Training Center is much better (more than half of the participants were females in 2012) however the offered courses are poor in diversity and target low wage categories. 


\section{Action Plan Rationale}

Entrepreneurial women give a contribution substantially to the economy, especially in times of limited growth, where job creation and private sector survival is challenging. By such contribution they offer significant opportunities to generate income, increase employment and reduce gender inequalities. Gender is a powerful role, which not only is important in our daily lives, but also in the organization were people work. Women constitute a large underrepresented group in Albania in terms of business start-up and ownership. Encouraging more women to become involved in enterprise and grow existing businesses will have a potentially positive impact on Albania's economic performance.

The National Strategy for Gender Equality, Gender-based Violence and Domestic Violence 2010-2015 was a serious step of the GA involvement gender equality and women's empowerment matters. The strategy laid the grounds for further actions to roll out government support for women's economic empowerment particularly in the areas of women's employment, skills, and female entrepreneurship. By the end of 2013, the Ministry of Social Welfare and Youth endorsed the Employment and Skills Strategy 2014-2020 (ESS), which aims to enable access to decent job opportunities, access to vocational education and training for youth and adults, promote social inclusion and territorial cohesion and achieve effective governance of the labor market and qualification systems in Albania (MSWY, 2014). During the same period, the Government of Albania drafted the new Business and Investment Development Strategy 2013-2020, as the main document for the identification and implementation of the national policies for the promotion of business investments for the period 2013-2020.

Although both strategies delve into women access to vocational education and labor market, creative economy and women entrepreneurship they lack a strong focus and clear agenda in support of woman entrepreneurship. To fill in this gap the Ministry of Economic Development, Trade and Entrepreneurship has approached UNWOMEN Albania with a request for technical support in developing an Action Plan on Women Entrepreneurship in Albania.

This Action Plan has been developed in response to a pressing need to encourage more Albanian women to start and grow their own businesses and to address positively the need for coordinated support for women's enterprise. The Plan aims to provide a collaborative long-term approach on the development of women entrepreneurship in Albania.

The Action Plan aims to:

- $\quad$ Promote an effective multi-governance approach to female entrepreneurship in the Albanian context

- $\quad$ Encourage development of government policies in support of the needs of women entrepreneurs

- Identify the key issues to be addressed through the development of strategic partnerships between the state and non-state actors at the local, national and regional levels

- Provide practical guidelines and examples of good practice from other countries in the region and around the world

- Highlight the change in culture and attitude needed to ensure that future SME development encourages women participation in business in both urban and rural areas.

For purposes of practical implementation of its goal and outcome, the plan is primarily aimed at GA, Local Government Units, Women NGOs, Banks, Donor Agencies and their specific programs, VET Institutions, Institutions of Higher Education, etc.

\section{Action Plan Development Methodology}

For purposes of this action plan the following definition of "female entrepreneur" shall be used:

"Female entrepreneurs are those who use their knowledge and resources to create new business opportunities either formally or informally who are actively involved in managing their businesses, are responsible in some way for the day-today running of the business, and have been in operation for longer than a year."

The team in charge of the development of the Action Plan selected e methodology that was participatory in nature and flexible enough to allow for necessary adjustments as more information and data became available. It followed a 4-step process as described below: 
Assessment of the situation: The assessment of the women entrepreneurship situation in Albania was mainly based on the use of secondary data. A thorough review of the relevant literature was carried out in order to create a complete picture of the current state of play of women entrepreneurship in Albania covering a number of available policy documents, reports and project publications. Further, a comprehensive analysis of the legal and policy framework with focus on EU legislation requirements was conducted by the consultants. An extensive consultation of documented best practices on women entrepreneurship was carried out and selected examples from other countries in the region and beyond were identified and incorporated in the Action Plan.

Stakeholder engagement process: The engagement process was based on interviewing an initial set of participants representing different stakeholder groups, such as Ministry of Economic Development, Trade and Entrepreneurship, Ministry of Social Welfare and Youth, Ministry of Agriculture, Rural Development and Water Administration, representatives from the NGOs and business community, donors and academia. Consultants followed a "snowball sampling" approach, whereby a small pool of initial subjects nominate other participants who meet the eligibility criteria for a study. The initial set of stakeholders suggested a list of other key stakeholders that were contacted during the process. During this step in the process consultants collected information about the interests of the various stakeholders in the action plan, the resources they could provide and the role they could play in the implementation of the plan.

Step 3. Selection of action categories: Selection of the action categories was based on the literature review and the information collected during the stakeholder engagement process. The initial set of action categories which was developed based on the literature review was revised after the consultation with relevant stakeholders. The action categories are described under the Framework for the Action Plan.

Step 4. Peer review process and validation: The peer reviewing process and validation was based on the utilization of a forum of stakeholders which were continuously informed during the action plan drafting. The forum meeting took place during January 2014 and served to fine-tune the action plan draft based on the reflection of the participants' comments. Finalization of the document took place during the end of January 2014 and the final draft was sent to MEDTE for approval.

\section{Conclusions and Recommendations}

The development of this Action Plan is an important step ahead to boost the entrepreneurship spirit among Albanian women. The document, a strategic tool, provides a synthesis of the contributions, analysis and vision of the key stakeholders and a follow-up of the overall attempts made in Albania in the last decade, with focus on women entrepreneurship. As such, it is in line with the GoA strategic plan on entrepreneurship and the UN vision on Women Economic Empowerment. Built on solid grounds, the plan is robust and includes ambitious goals and outcomes that will be impossible to attain, unless strong commitment by multiple stakeholders representing the government, NGOs, business sector, academia and the donor community is ensured.

The successful implementation of this plan calls for:

- Establishment of a multi-stakeholder policy advisory group, with METDE as the hosting institution, to provide a focal point for women entrepreneurship-related issues and to support the successful implementation of the action plan.

- Designation of a coordination unit within METDE to oversee the implementation of the action plan.

- Setting up of Women's Business Center to assist female entrepreneurs with education, training, coaching, and mentoring services and access to finance.

- Development of a detailed Monitoring and Evaluation Plan and Baseline Data, and Indicators Report.

- A fund-raising strategy that outlines current funding available and strategies for securing additional funds from different sources.

- An increasingly adjusting process with the changes occurring in the enabling environment, so that the plan stays relevant and responsive

- Increased attention on the cultural and attitudinal changes related to female entrepreneurship in Albania, especially in rural areas.

\section{References}


[1] Agolli, M. , 2013, Assessment on the need to strengthen entrepreneurial training programs and partnership with businesses in VET and life-long learning programs. GIZ, Tirana, Albania.

[2] Bezhani, M. , 2008, InFocus Program on Boosting Employment through Small Enterprise Development Job Creation and Enterprise Department Series on Women's Entrepreneurship Development and Gender in Enterprises. WEDGE Women Entrepreneurs in Albania.

[3] European Commission, 2008, Small Business Act for Europe. Brussels, Belgium.

[4] European Commission, 2013. Entrepreneurship 2020 Action Plan. Brussels, Belgium.

[5] Government of Albania, 2011, National Strategy on Gender Equality and reduction of Gender-based and Domestic Violence, 2011-2015. Tirana, Albania

[6] INSTAT, 2012, Albania Time Use Survey 2010-201. Tirana, Albania

[7] ISB, 2013, Study on Women Entrepreneurship in Albania. Tirana, Albania

[8] Mandro-Balili, A. , 2013, Women Property Rights: Analysis of the Legal Standards and their De-facto Implementation - The Case of Albania. UNWOMEN, Tirana, Albania.

[9] MEDTE, 2013, Business and Investment Development Strategy. Tirana, Albania.

[10] Miluka, J. , 2011, Gender Wage Gap in Albania. Tirana: MLSAEO\& UN Women. National Report on the Status of Women and Gender Equality in Albania 2011. Tirana: MLSAEO\& UN Women.

[11] MARDWM, 2012, Agriculture Statistical Yearbook. Tirana, Albania.

[12] MES, 2013, Education figures. Tirana, Albania.

[13] MES, 2012, Vocational Education in Albania. Tirana, Albania

[14] MSWY, 2014, Employment and Skills Strategy 2014-2020: "Higher skills and better jobs for all women and men, " Tirana, Albania. OECD, et al. , 2012, SME Policy Index: Western Balkans and Turkey 2012: Progress in the Implementation of the Small Business Act for Europe, OECD Publishing.

[15] http://dx. doi. org/10. 1787/9789264178861-en

[16] PBWHA. , 2013, Assessment of the Environment for Women Entrepreneurship in Albania. ILO, Tirana, Albania

[17] UN Women, 2011, National Report on the Status of Women and Gender Equality in Albania UN Women. Tirana, Albania

[18] Voell, S. , 2004, "North Albanian Customary Law Kanunas a Habits, " paper presented at 8th EASA Conference "Face to face: Connecting distance and proximity, " Department of Social and Cultural Anthropology, University of Vienna.

[19] Wheeler, R. , 1998, "Past and Present Land Tenure in Albania- Patrilineal, Patriarchal, Family- center, "Land Tenure Centre, Albanian series, Working Paper No. 13, University of Wisconsin.

[20] Wheeler, R. , Waite M. , 2003, "Albania Country Brief- Property Rights and Land Market, " Land Tenure Centre, University of Wisconsin, USA.

[21] World Bank, 2006, "Status of Land Reform and Real Property Markets in Albania, "Tirana.

[22] Zhllima, E. , Viaggi, D. , and Muller, D. ,2010, "Property Rights of Land and its Perception in Rural Part of Central Albania, " paper prepared for NEW MEDIT Journal No 3.

[23] Zhllima, E. , 2012, Analysis of Development Project Models Implemented for the Economic Empowerment of Women in Albania. Tirana: UNDP.

[24] Zhllima, E. , 2013, Gender Analyses of Extension Services for the Ministry of Agriculture, Food and Consumer Protection in Albania. Draft consultancy report. Tirana: UN Women. 